\title{
7. 'Mothers of the Nation': The Ambivalent Role of Motherhood in Assad's Syria and the Non-liberatory Subject
}

\subsection{Introduction}

In the second half of the 2oth century, Syria went through a phase of state development that included fairly secular features; however, the personal status law in Syria remained based on the Shari'a law. This dual system of both secular and religious courts left Syrian women vulnerable to discrimination. Although there is an existing personal status law that permits women to take control over "issues related to marriage, divorce, custody, and other family matters," the patriarchal values and the laws tied to the Shari'a law continue to have a huge impact. For instance, marital rape and domestic violence are not recognized by the law, and marriage contracts must be filed between the father of the bride and the groom (Charles and Denman, 2012). If a divorce must take place, the man can simply order this divorce by going to court and requesting it verbally three times in a row. However, for a woman to request a divorce, she first needs her husband's approval and must prove to the juridical court that she has a valid right for a divorce; for example, she must have proof that she was abused or neglected by her spouse. Moreover, a husband in Syria can forbid his wife from working outside the home and is entitled to forbid her from travelling outside of Syria (Freedom House, 2010). But because the personal status law is arbitrary, most of these prohibitions can be toppled if women in Syria were more informed about their legal rights. For instance, a study done by Freedom House (2010) revealed that:

"Many [Syrian] women, particularly those living in rural areas, do not fully understand their legal rights and cede what rights they do have in response to social or family pressure. This is particularly evident with respect to prop- 
erty rights. The unequal inheritance rights mandated by Shari'a-based laws are commonly justified by the requirement that men provide for the women in their family, but women often turn over the entirety of their inheritance to their brothers to keep it in the family. Such practices greatly exacerbate women's financial dependence on men."

Therefore, although women can normally be active in Syrian society, there are arbitrary laws and patriarchal norms that drastically limit their participation in many political, social, and cultural features of their daily life.

After the war began in 2011, Syrian women faced greater and newer obstacles. Many became victims of war rape, a tactic used by both the Syrian regime and the opposition forces to pressure the opponent. Other women suffered from honor killings in areas held by extremist and terrorist groups, such as Daesh (ISIS) and Al Nusra Front. In the television coverage of the war, Syrian women were predominately represented as victims of violence; however, there were other images that showed women taking part in activities of armed and unarmed resistance.

For instance, the Assad regime formed an army unit that included only female soldiers. Political analysts have asserted that the regime's decision to recruit female fighters in the so-called armed resistance comes from Bashar Al-Assad's motivation to portray his forces as a 'progressive and secular alternative' in the face of the forceful Islamists in Syria (Leduc, 2015). Granted, this creation of female battalions is not a new project in Assad's Syria. Hafez Al-Assad, the father of Bashar Al-Assad who governed Syria from 1972 until 2000, also created a female army unit as part of the regime's propaganda to represent itself as secular and modern (Macdonald, 2016). For propaganda purposes, the Syrian regime has long stressed the important roles women play in Syria, which include those of the female fighters in the Syrian Arab Army. These images are not merely empty representations for the sole purpose of appealing to the West. Syria has a long history of women's empowerment.

In the 2oth century, Syria's first women's organization, known as the Light of Damascus (or Noor al-Fahya in Arabic) was formed by mostly educated upperclass women. Nazik Al Abid was the main founder. Aside from her activism in women's rights, $\mathrm{Al}$ Abid boldly criticized the long presence of the Ottomans in Syria and condemned French colonialism in the region (Arenfeldt, \& Golley, 2012). She was granted an honorable rank in the Syrian Arab Army after she heroically fought in the Battle of Maysaloun; she later established the Syrian Arab Red Crescent in 1942 (Zachs, 2013). 
When the Ba'ath Arab socialist party took power in Syria in 1963, equality between men and women was one of the main political reforms in the Syrian constitution. As part of the reformations, GUSW, or General Union of Syrian Women, a women's rights organization, became affiliated with the ruling party and part of the government structure. This gave GUSW a great advantage, as other similar organizations were no longer allowed to operate outside the control and political structure of the Syrian regime (Arenfeldt \& Golley, 2012).

GUSW held several events during the recent conflict in Syria. Their events on International Women's Day were widely reported by television stations owned or controlled by the Syrian regime. The television news reported these events by focusing on a diverse group of Syrian women: women activists, women on the battlefield, women supporting the Syrian Arab Army, etc. The reporting also emphasized notions of resistance, solidarity, and sacrifice, associating these with the role of motherhood.

These representations have widely existed in dominant narratives of nation states. In the book Woman-Nation-State, Anthias and Yuval-Davis (1989) asserted that the link between women and the state is multifaceted. Different government institutions, such as schools and trade unions, as well as communication structures, such the mass media, can formulate dominant state narratives that idealize the participation of women in the nation-building processes. Many of those roles have aspects of motherhood. Anthias and Yuval-Davis (1989) explained:

"On the one hand, [women] are acted upon as members of collectivities, institutions, or groupings, and as participants in the social forces that give the state its political projects in any particular social and historical context. On the other hand, they are a special focus of state concerns as a social category with a specific role (particularly human reproduction). It is important to note, however, that these roles cannot be understood in relation to the state reproducing itself or that any absolute control by the state would be achievable, given women's incorporation at a number of other social levels within civil society and in the economy" (p. 6).

Syrian women who appeared in the news reports were portrayed participating in different roles to serve the nation, such as: the duty to bear children; the duty to transmit and maintain culture and national identity; and the duty to participate in the armed and unarmed resistance. These responsibilities bare a strong resemblance to what Anthias and Yuval-Davis (1989) have described 
as "the major ways women participate in the national processes." Their study showed how national narratives portray women,

"...as biological reproducers of members of the nation, as participating centrally in the state ideology reproduction and the transmitters of its culture, as participating in national, economic, political and military struggles" (p. 7).

Table 8. A comparison: the different roles of women towards the nation

\begin{tabular}{|l|l|}
\hline $\begin{array}{l}\text { Roles of Women in Nation-Building } \\
\text { by Anthias and Yuval-Davis }\end{array}$ & $\begin{array}{l}\text { My Findings in the News Reports } \\
\text { Analysis on Syrian Women in As- } \\
\text { sad's Syria }\end{array}$ \\
\hline $\begin{array}{l}\text { "As biological reproducers of members of the na- } \\
\text { tion" }\end{array}$ & The duty to bear children \\
\hline $\begin{array}{l}\text { "Participating centrally in the state ideology repro- } \\
\text { duction and the transmitters of its culture" }\end{array}$ & $\begin{array}{l}\text { The duty to transmit and maintain } \\
\text { culture and national identity, }\end{array}$ \\
\hline $\begin{array}{l}\text { "Participating in national, economic, political, and } \\
\text { military struggles" }\end{array}$ & $\begin{array}{l}\text { The duty to participate in the armed } \\
\text { and unarmed resistance during the } \\
\text { conflict }\end{array}$ \\
\hline
\end{tabular}

In this chapter, I examine news reports from television stations owned or controlled by the Syrian regime. The news reports represented different groups of Syrian women in relation to the notion of resistance, both armed and unarmed. In the analysis, I show how these representations are related to what Anthias and Yuval-Davis (1989) termed 'the national processes,' by looking at how motherhood was the main duty ascribed to Syrian women participating in the so-called armed and unarmed resistance.

\subsection{Research Data}

My analysis takes eight news reports from four main television stations, SAMA (three news reports), SANA (three 3 news reports), RT Arabic (one news report), and Syria Al Ikhbariyya (one news report). RT Arabic sympathizes with the Syrian regime, SANA, SAMA, and Syria Al Ikhbariyya are controlled by the Syrian regime. The sample selection was conducted in two main steps. Firstly, I went on the YouTube channel of each television station and used the search engine, entering the following keywords: Syrian 
women, Syrian conflict, armed resistance, unarmed resistance, rebellion, fight, battle, struggle, military, sacrifice, weapons, defense, and opposition. These keywords were purposely selected to collect news reports related to the context of resistance. The resulting news reports were few in number; only fourteen videos met the criteria. The second step was to select the most relevant news reports. I watched each news story three times. The relevance of the content was measured in terms of context (the Syrian conflict), and date of publication (the news story should be published between 2013 and 2018). Afterwards, eight news reports of the fourteen were selected for the case study sample. The news reports were published between April 2, 2013 and September 27, 2018. The table below lists details about each news report:

Table 9. The news reports in the context of resistance

\begin{tabular}{|c|c|c|c|c|c|}
\hline $\begin{array}{l}\text { Re- } \\
\text { port }\end{array}$ & $\begin{array}{l}\text { Tele- } \\
\text { vision } \\
\text { Station }\end{array}$ & Title of the News Report & $\begin{array}{l}\text { Dura- } \\
\text { tion }\end{array}$ & $\begin{array}{l}\text { Date } \\
\text { Published }\end{array}$ & $\begin{array}{l}\text { Chap- } \\
\text { ter } \\
\text { Sec- } \\
\text { tion }\end{array}$ \\
\hline 1 & $\begin{array}{l}\text { Syria Al } \\
\text { Ikhbariyya }\end{array}$ & $\begin{array}{l}\text { The Braids of Fire: From } \\
\text { the Front, They Came Di- } \\
\text { rectly with their Military } \\
\text { Clothes }\end{array}$ & $25: 33$ & March 21.2018 & 7.3.1 \\
\hline 2 & SAMA & $\begin{array}{l}\text { International Women's } \\
\text { Day Syrian Women Give } \\
\text { Back to Society }\end{array}$ & $1: 23$ & March 8, 2018 & 7.3.2 \\
\hline 3 & SANA & $\begin{array}{l}\text { On International } \\
\text { Women's Day, Syrian } \\
\text { Women Embody the Act } \\
\text { of Sacrifice and Heroism }\end{array}$ & $1: 43$ & March 8, 2018 & 7.3.2 \\
\hline 4 & SAMA & $\begin{array}{l}\text { Under the Slogan } \\
\text { "Women are a Home- } \\
\text { land in a Homeland ... } \\
\text { the Syrian Women Have } \\
\text { a Meeting." }\end{array}$ & 2:09 & $\begin{array}{l}\text { September } 27 \\
2018\end{array}$ & 8.3 .2 \\
\hline 5 & SANA & $\begin{array}{l}\text { A Lecture on Resistance } \\
\text { with the Women Forum } \\
\text { and the Dialogue of Civi- } \\
\text { lizations }\end{array}$ & 2:19 & March 132017 & 8.3 .2 \\
\hline
\end{tabular}




\begin{tabular}{|l|l|l|l|l|l|}
\hline $\begin{array}{l}\text { Re- } \\
\text { port }\end{array}$ & $\begin{array}{l}\text { Tele- } \\
\text { vision } \\
\text { Station }\end{array}$ & Title of the News Report & $\begin{array}{l}\text { Dura- } \\
\text { tion } \\
\text { Published }\end{array}$ & $\begin{array}{l}\text { Chap- } \\
\text { ter } \\
\text { Sec- } \\
\text { tion }\end{array}$ \\
\hline $\mathbf{6}$ & SANA & $\begin{array}{l}\text { Syrian Women: Success } \\
\text { stories and Strong Will } \\
\text { during Difficult Times } \\
\mathbf{7}\end{array}$ & $\begin{array}{l}\text { SAMA } \\
\text { Sillages of Hama are } \\
\text { Preparing Food for the } \\
\text { Heroes of the Syrian } \\
\text { Arab Army }\end{array}$ & March 3, 2017 & 8.3 .2 \\
\hline $\mathbf{8}$ & RT Arabic & $\begin{array}{l}\text { A Collective Wedding } \\
\text { Celebrates 30 Syrian } \\
\text { Arab Army Soldiers }\end{array}$ & $2: 04$ & April 2, 2013 & 8.3 .3 \\
\hline
\end{tabular}

In these news reports, different Syrian women were depicted in diverse contexts and situations: women serving in the military, women serving food to male soldiers, women marrying soldiers, and women taking part of social and cultural events on women's rights organized by the GUSW. Although these groups of women came from different demographical and socio-economic backgrounds, the notion of 'mother of the nation' appeared in all the representations- regardless of whether the women were actual mothers. I explore these depictions in the analysis section of this chapter.

\subsection{Analysis}

\subsubsection{From Manly Fighters to Ornamented Flowers}

This subsection focuses on the Syrian women's participation in the armed resistance in Assad's Syria.

I start this section by focusing on a 25 -minute news report published by Syria Al Ikhbariyya ${ }^{1}$ on March 21, 2018. The news story covered a Mother's Day

1 Syrian News Channel is an Arab satellite television station based in Damascus, supportive of the Syrian regime. 
ceremony organized by the Ba'ath Party; the political party that has been leading the Syrian government since 1963. Asma Al Assad, the first lady of Syria, appeared in the news report and gave a speech honoring the girls and women of Syria, specifically the young female fighters in the Syrian Arab Army and their mothers.

Asma started her speech by thanking the young female fighters. She said:

"We are proud, and we appreciate and acknowledge all the things you have done, and you are doing alongside with your families. This is what everyone should see, that Syria was being defended by everyone, everyone without any exception, including its young women. The young women that hid their long hair, and put their dreams on hold, and left their parents, and wore the military attire instead of the wedding dress, and carried the guns instead of their educational books, and they went to defend the soil of their homeland."

As she described the female fighters, her speech hinted at the idea of 'having to let go of one's femininity' by hiding one's long hair, by choosing to volunteer in the military rather than pursuing a marriage, and by leaving school in order to defend the homeland. She continues by reminding her audience of the significant history of 'the Syrian woman.' Asma pointed out how the Syrian woman was always ahead of other Arab women in her historical accomplishments. She addressed Syrian women in a singular form and said:

"The woman in Syria has been for a hundred years and she probably was the pioneer among all the women from the other Arab countries. She was the leader in many disciplines. She was the first female doctor, the first female pharmacist, the first female journalist, the first female ambassador, the first female judge. From the times of Zanubiya to Nazik Al Abid, until today."

Afterwards, she incorporated the notion of 'us versus them,' by hinting at the opposition's female fighters. Asma said:

"When I say sacrifice and defense, of course I mean it through taking action, not through 'talking, or the 'media' or 'advertising' or 'propaganda,' as the others have already done. They dressed them up and sent them under the slogan of 'defending the nation,' and they made them recite a few words, and they snapped a few staged photos of them. And then they pushed for the country's segregation. During this time, you, and the other female and male fighters were sacrificing everything to keep this country unified." 
In her speech, Asma tried to portray the female fighters in the Syrian Arab Army as 'authentic' by drawing a comparison to the other female fighters from the opposition, claiming that they are merely pawns used by rebels to segregate Syria. Later on, she condemned gender discrimination, insinuating that the Syrian State endorses unity and equality among the two genders. Asma said:

"Syria, to you, means unity. And for Syria, Syria means that you and all the fighters are one entity. When you went on the battlefield to defend Syria with your own bodies, you faced death, and saw death face-to-face, but in these instances, you eliminated the difference between a man and woman. When the bullet passes by you on the battlefield, it does not differentiate between a female or a male, or a girl and a boy, or a female fighter and a male fighter. In death there is no gender differentiation, therefore in life there should not be any gender discrimination. This is what you have shown the world, you let all the world see you as human beings. A strong human being, a capable human being with great determination, with a solid will that no one can break."

The news reporter then tried to reaffirm the 'presence' of the non-existent gender differentiation and discrimination in Assad's Syria, by interviewing the mothers of the female fighters. One mother said:

"I remember I raised her the same way I raised her brothers. I don't differentiate between them."

Another interviewed mother said:

"In Syria, a girl is the sister of the man. Just like we have male heroes, we have female heroes as well."

These statements allude to Ba'ath's narratives on gender equality and national unity. In the context of this news report, the resistance and solidary of the Syrian female fighters, were demonstrated as a unifying symbol of a nation that condemns gender differences. Yuval-Davis (1997) wrote: "Women are often constructed as the cultural symbols of the collectivity, of its boundaries, as carriers of the collectivity's honor and as its intergenerational reproducers of culture" (p. 67). Granted, Ba'ath always tried to mobilize women politically, not as Syrian women, but rather as Syrian citizens; "citizens with the same rights and duties as their male compatriots" (Sparre, 2008, p. 8). 
In the news report, the representations of 'same rights and duties' for both male and female fighters appear, as one female fighter was shown speaking on the phone to her father, while she sat in a sniper's room.

In the news report, the father told the daughter over the phone:

"Please take care of yourself, may Cod protect you."

The daughter answered:

"Don't worry father, you have given birth to men, not girls."

He responded:

"I know I have given birth to men, not girls."

In this conversation, aspects of masculinity became associated with the image of the female fighter. These representations did not express a neutrality in gender. Although the first part of the news report attempted to frame the female fighters as 'equal counterparts in the Arab Syrian Army. In the second part, the representations embodied the female fighters as 'men' because they are active in military.

Afterwards, notions of femininity were introduced in the news report, as Asma Al Assad complimented the physical beauty of the female fighters. She said:

"I know you have lost many battles in this war, but I am very certain that you have never lost, and that you will never lose how beautiful you are as girls. You are very beautiful. You ornamented the Sham with your beauty, you ornamented all the governorates of Syria!"

This part of her speech came as a reaffirmation, as a way to comfort the female fighters, telling them that their resistance and solidarity on the battlefield did not and will never threaten their femininity. This indicates that aspects of their physical female appearance remain important. Afterwards, she addressed the mothers of the female fighters. She said:

"There are mothers here who had their sons murdered or injured, while their daughter was on the front. I know that there are mothers here who have not only one daughter on the front, but two daughters, two daughters!"

She continued by describing what motherhood really means to Syria, extending the definition to not just the notion of creating a family, but also to the notion of sacrifice, specifically sacrifice for the homeland. She said: 
"Motherhood is greatness. Motherhood is not just about conceiving children. The greatness of motherhood is about sacrifice. The mother should sacrifice her soul for the homeland."

Afterwards, Asma Al Assad congratulated the female heroes on their accomplishment, their faithfulness and most importantly on not just acting as if they are the 'mothers of Syria,' but for also becoming 'mothers of Syria' through their sacrificed and the time they spent on the battlefield. She emphasized the female fighters' femininity by comparing them to flowers. This came as a contradiction to her previous statement that insinuated that a 'good' and 'true' Syrian family raises its children without any gender discrimination. She ended her speech by saying:

"There is no female hero, there is no male hero without sacrifice, without courage, without greatness, without a complete family. A female hero and a courageous one. A complete family, that raised its daughters like its sons. And made everyone great like a human being, without any discrimination. On the basis of the same principles and values, and according to high qualities from patriotism to the love of the land. and for this reason, it would have been impossible not to have you here, at this ceremony on Mother's Day. It is impossible for you not to exist, because your mothers have raised you that way. And it would have been impossible to congratulate your mothers without your presence, the daughters' presence. Because this flower from this holy soil, and this holy soil is the one that raised and made the flowers grow bigger, and their brothers from the Syrian Arab Army. And these flowers, although when needed they become thorns, but they are at the same time mothers. They are the mothers of today, not just because they are defending Syria (we all know Syria is our Greatest Mother), but they are defending Syria also because Syria is like their little son or daughter that needs their care and their sacrifice in blood. You are the mothers, morally at the moment. And of course, in the future, inshallah, you will be real mothers. Because every look in your eyes has so much strength, and this will never eliminate the essence of companionship and tranquility and calmness, in which the woman provides in life."

These representations of the female fighters were somehow contradicting. The fighters were initially depicted as strong human beings on the battlefield, regardless of their gender. Afterwards, they were addressed as 'men' on the battlefield. Later on, metaphors were used to objectify the female fighters as flowers that have ornamented Syria or as flowers with thorns. The last depiction incorporated ideas about the female fighters' destiny, which was di- 
rectly tied to their femaleness; they were destined to act as the 'mothers of the nation'. This was reaffirmed when one of the mothers in the new report said:

"I tell my daughter Happy Mother's Day, instead of expecting my daughter to greet me for Mother's Day."

The images of the female fighters were linked to the idea of "remaining feminine, and not to give the impression of being overly masculine" (Schuring, 2014). The importance to maintain one's femininity and to fulfill one's role as 'mothers of nation while also participating in a generally masculine occupation was articulated in the reporting. However, we cannot deny that the images challenged the common orientalist assumption that women in the Arab world are fundamentally oppressed and 'need saving (Mohanty, 2003); the female fighters were depicted as the new heroines of the Syrian State. By encouraging women to join Syrian Arab Army, Ba'ath emulates the Kurdish female fighters in the PYD and the policy of gender neutrality and equality on the battlefield. However, it is important to point out how the news report does not reveal the socioeconomic status of the female fighters, and perhaps conceals the fact that only girls from poor families are likely to become fighters. We also notice that most of the female fighters are young and unmarried. Hence, this discloses how the young female fighters may remain subjected to patriarchal interpretations of traditional Syrian society. Although they might be carrying guns, the male figures in their life remain present and dominant, as shown with one of the fighters who spoke to her father on the phone. Furthermore, only young and unmarried women are allowed to join the military in Syria, in this way the Syrian regime is able guarantee the female fighter's honor and sexual purity. Building on that, I would argue that these groups of women are not entirely toppling patriarchal norms, but perhaps only escaping them temporarily on the battlefield. Meanwhile, their representations also remained framed by stereotypical gender binaries such as 'ornamented flowers,' and 'mothers of Syria.'

\subsubsection{Motherhood as a National Duty}

This subsection analyzes the news reports on the Syrian woman's unarmed resistance. The reporting mainly focused on the Ba'ath party's policy for equality and gender neutrality. The General Union of Syrian Women (GUSW) is the only licensed governmental women's rights organization in Syria. This is because, under the Syrian government, it is illegal to permit any human rights 
organizations that are not controlled by the state itself. Since Ba'ath runs the Syrian government, GUSW is only allowed to work according to the rules and policies of the political party. It focuses on women issues, as well as projects on 'illiteracy, early childhood education, and natal health' (Alous, 2017). I found three news reports by SANA and two news reports by SAMA published between 2017 and 2018. The news stories reported on the events held on international women's day and other events on women empowerment that took place under the organization of the GUSW and Ba'ath. The Syrian woman's role in society was always the core topic of the dialogues and discussions that took place during the events.

SAMA published a news report on international Women's Day, on March 8, 2018. The reporter conducted Vox Pop interviews with Syrian women attending the event organized by GUSW. ${ }^{2}$. They were asked about the role of Syrian women in Syrian society. The reporter started by saying:

"During International Women's Day, the Syrian woman is 'the greatest source of giving back to society' as she is aware of huge amount of work she accomplishes daily, she is inspired by the generation of her grandmothers, who are the root of her history."

The women interviewed were asked to give their opinions on women's rights in Syria. Most of the answers highlighted the significant role Syrian women play in society, such as the caregiver, the hard worker, the teacher, and the mother. The interviewees saw that as an integral part of women's rights in Syria. The first response was concerned with how the Syrian mother raises her children:

"The Syrian woman is building our society, she is raising heroes, she is raising the young men. The Syrian woman has a strong role in our society."

The second response was:

"The Syrian woman has a role in raising the children, to direct them to what is wrong and what is right. She should take them away from what is wrong, and direct them toward the right path."

These statements insinuate that the Syrian mother is the person who will guarantee that the future generations will not go 'down the wrong path,' or 2012; it is politically supportive of the Syrian regime. 
join the opposition groups. The third response addressed how the Syrian woman is expected to be a perfectionist, whether at home or in the work place:

"If she is married, she should raise her children in a lawful way. If she is a working woman, then she should conduct her job in a perfect way."

The fourth response also spoke about perfectionism, and the Syrian woman's duties to love the nation and the president:

"In terms of working women, the Syrian woman should be dedicated to her job, she should love her motherland, she should love the leader of our motherland. She should accomplish and be perfect in everything she does in life."

On March 8, 2018, SANA reported on an event that hosted a number ofleading Syrian women from the Ministry of Administrative Development. ${ }^{3}$ It was another honorary ceremony under the title of Women's Leadership, Work and Development that took place on International Women's Day in Damascus. The female Minister of Administrative Development, Dr. Salam Safaf, was interviewed. ${ }^{4}$ He said:

"The Syrian woman is culture, the woman is history, the woman is power, power for work, power for development. The Syrian woman was present in all the fields. She was present in the construction field, in the creative field, medicine, cultural, military, even the resistance. She was present in any field that has all the capabilities, capacities and the potential in our society. She was never dismissed or excluded."

A female member of the Syrian People's Council, Janet Kazan was also interviewed. She said:

"All the resistance, and all the challenges we face by us, the Syrian women challenged the whole world in this war that came to our land. It is not only the mother of the Martyr that took part of this challenge, but we also have many women who participated in this battle, by giving up their comfort and their state of mind. Other women had a living martyr at home, whether it is the husband or son."

3 A television station owned by the Syrian state (Syrian Arab News Agency 2019).

4 Minister in Arabic was written in its masculine form, not in its feminine form, although the interviewee was a woman. 
Moreover, Shahira Fallouj, the Director of the General Authority for Schools for Sons and Daughters of the Martyrs, spoke. ${ }^{5}$ She said:

"Honestly, we are proud that us women are Syrian. During this ceremony, I would like to say to the mothers of the martyrs that they are heroes. She is not only a hero in Syrian history, but also a worldwide hero."

On September 27, 2018, SANA reported on a meeting organized by the Directorate of Culture in Jaramana, in the Damascus Governorate. The meeting introduced the first open dialogue on the role of Syrian women in society. Its slogan for the event was 'The Syrian woman is a home in a Homeland.' The reporter said:

"One is wrong to assume that the woman is the weakest element during a conflict. The Syrian woman has proven that she is the strongest factor for resistance and solidarity, especially in the shadow of the conflict and the circumstances we are passing through. She is the person that taught the world the true meaning of patience and the act giving for the sake of the homeland, its sovereignty, and its dignity. She has a record of sacrificing acts and positions she has taken for our communities. These important positions she has taken are nothing new to the Syrian woman. The Syrian woman had a strong role in building society, and she has still this responsibility until today."

The reporter then interviewed Colonel Hala Bilal from the Office for the Care of the Wounded in the Internal Security Forces. ${ }^{6}$. She said:

"The Syrian woman is a home in a homeland, because we women are a home, and the woman is a root or the base for the homeland. She is the one that creates the household, and the household is a family, and the family is based on children, and the children are the saviors and the protectors that kept Syria safe."

The reporter continued by saying:

"When the role of the Syrian woman was rising and gaining more significance, especially for her will to participate in politics, she was given all the care and attention, her career was supported, and her bid was valued. We

The word director in Arabic, was written in its masculine form, not in its feminine form, although the interviewee was a woman.

6 The word colonel in Arabicwas written in its masculine form, not in its feminine form, although the interviewee was a woman. 
made her a key partner in making history. During that time, dialogue sessions should have been established in order to shed the light on the Syrian woman's role as a mother, a caregiver, and a fighter and a resister."

Another commenter was Layla Saab, the Director of Culture in Rural Damascus. ${ }^{7}$. She said:

"The Syrian woman has proven that she is a legend for resistance, and a legend for reconstruction. And regardless of all the challenges she faced, and all the pain she went through, she is still insisting on survival and resistance."

Afterwards, the reporter ended the report with the following statement:

"A Syrian woman has a big and significant role. She is the one that creates society, and she plays a major role in sustaining a good and healthy society and educating this society. And she is behind every victory recorded in history. She is no longer half of the society; she is the basis of it."

A similar news report published on March 13, 2017 by SANA reported on a forum that included a lecture on women resistance and in dialogue with Syrian civilization. In Mazza Damascus, organized by Youth Union in Syria. 'The Woman for Resistance' was the title of the event. The reporter started with the following statement:

"The Syrian woman is the one that got prepared and helped to prepare, the one that planted and harvested, resisted and triumphed, participated and shared. From home education to educational upbringing, reaching social life, she is the one with the biggest role."

Vera Yammeen, a member of the Ba'ath Party, said:

"Syria was always a country that provided a platform and space for people with competencies. And for this reason, as long as the Syrian woman is active in this country, the Syrian woman that symbolizes upbringing and education, the woman that symbolizes national identity, that symbolizes this land. Therefore, is it not a surprise that today, the Syrian woman is very active in social life. If the woman were not active, we would not have a stable and balanced society. And the social stability is what leads to the satisfactory outcomes, especially that, today, we began debating, in one way or another, about the solutions needed and the adjustments needed

7 The word director in Arabic was written in its masculine form, not in its feminine form, although the interviewee was a woman. 
to set us on the right track. Therefore, for this reason, when I talk about the woman, I do not talk about her as a separate body or element, but rather, the complete opposite. I see her as a basic part of a well-balanced social structure, because there is no balance, not in the social life, and not in the political life, and not in the national life, not without a balance between man and woman, together. And this is what the Syrian women has proven and was devoted for. When Syria acts as a caring mother, then the Syrian woman becomes a reflection of this culture."

SANA published a news report on March 3, 2017 with the title "Syrian women: Success stories and Strong Will in Difficult Times." This was the only news report that covered issues related to the low number of female representatives in Syria' People Council, sexual harassment in Syria, and the lack of laws that protect women. The news reporter started with the following statement:

"After she has proved her active presence alongside the man, in all aspects of life, and she showed great resistance and courage during the war that has been waged against her nation, she was the mother, the worker, and the fighter, the Syrian woman deserves a parliament that acknowledges her struggles and aspirations, in a safe space, where laws and legislations are enacted to protect her rights."

This statement suggests that Syrian women should have a more active presence in Syria's People Council and there should be a higher number of female ministers. An unnamed woman was interviewed. She gave her opinion on the low female representation in the People's Council. She said:

"I believe that the number of women in Syria's people council should increase. One of the reasons for that is how the percentage of Syrian women in the Syrian population became higher than the number of men after the war. Therefore, the number female representatives in Syria's people council should reflect on the female population in Syria. It is impossible for male representatives, regardless of their consciousness and empathy, to be able to engage in women's issues as much as a female representative could. Therefore, the women's presence in the People's Council will have a positive impact on women's rights and accomplishments in Syria."

Another unnamed woman addressed the need for Syrian women to practice their voting rights and be active in the voting process. She said:

"I would like to see the Syrian women take part of the voting process in the People's Council in Syria. However, I hope and ask each woman participating in this voting process, to be faithful and follow the ideas she hopes to implement in the People' Council. She should not forget who and what she is fighting for." 
A different interviewee also addressed the need to change Syria's laws and policies to benefit of Syrian women. She said:

"The minimum number of female representatives in the people's council should be at least $40 \%$. If she is my representative, and a representative to the council, that means her dreams are like my dreams. But what are my dreams? I am currently in need of safety. I need to feel safe emotionally, physically, and economically. She should help me accomplish this."

The same news story from SANA also addressed the issue of sexual harassment in Syria and the non-existent laws that grant women protection. One unnamed woman was interviewed; she spoke indirectly about the sexual violations that were committed during the conflict. She said:

"I ask from our government to thoroughly examine the economic situation in our country, and the social life as well. In our society, especially during the difficult times in war, certain events happened. There should be a more thorough study on the laws in the country, especially to the benefit of the Syrian woman. As you know, the Syrian woman became a victim in certain situations, situations in which the terrorists were involved. There have been incidents of rape and torture. Therefore, we need to study the laws that will protect her in the future. The most important thing is to make sure that Syrian woman is protected by the law in our society. It is also important to enlighten the Syrian woman about those laws."

Most of the news reports surveyed in this section represented the idea of the tanwir or the enlightening process that the Syrian regime has long been promoting in its ideological narratives (della Ratta, 2012). There was a dominant narrative being pushed regarding the national role Syrian women should play during the conflict. The Syrian women interviewed in the news reports did not wear a headscarf. This may indicate that the Syrian regime is attempting to appear modern and secular in its media images. The Syrian women interviewed also had high-ranking governmental positions such as directors, colonels, ministers. It is important to point out that, in the reporting, their titles were in the masculine form. In Arabic, the words director, colonel, minister, etc. are declined according to the subject's gender. The female speakers were given a 'masculine' title instead of a 'feminine' one. In her research on educated women in Syria, Sparre (2008) wrote: 
'Unlike the ideology of 'neo-patriarchalism,' which emphasized women's roles as mothers and wives, the state feminism ideology of the Ba'th Party portrayed women as muwazzafin (public employees)."

Muwazzafin is the plural for the word employee, but for a group of men, not women. The feminine form of this word is muwazzafaat. Hence, the Syrian constitution's declaration of forbidding discrimination on the basis of gender may perhaps explain why the women interviewed in the news reports had their title addressed in a masculine form.

Moreover, another aspect that attracted my attention was that none of the reports portrayed or interviewed any Syrian women from a working-class background. The news stories only spoke on behalf of the subjects. The news reporters and the interviewees spoke about one Syrian woman, painting her in a single image, as if she were one entity, had one face, and came from the same demographical background. Hence, we do not really see who or what or how different groups of Syrian women have accomplished their acclaimed forms of resistance or how they have embraced solidarity, triumphed, and fought using their female roles alongside men in Syria. We only saw women with high-ranking government positions appealing to the Syrian women to rise, resist, and be empowered.

Granted, the reality in Syria shows that there are also very few women in high-ranking positions in the country. Research done by UNIFEM (2007) claimed that:

"Syrian women hold high ranking positions in all government and civil institutions, vocational unions, popular organizations and the doctors/pharmacists/ lawyers/ artists/ teachers/ workers/ artisans/ farmers/unions but in unsatisfactory numbers."

In her speech, Asma Al Assad glorified the Syrian woman's history and her accomplishments. For example, she mentioned how the Syrian woman was the first Arab women to become a leader in many disciplines; the first female doctor, the first female pharmacist, the first female journalist, the first female ambassador, the first female judge. At the same time, she disregarded the low number of Syrian women in high-ranking positions.

Furthermore, 'the Syrian woman' was always associated with the following labels and roles: the basis of the homeland, the legend, the international hero, the person that creates a good and healthy society, and the person who rebuilds what the war has taken away. These representations are flattering 
and empowering, but they remain an exaggeration of the reality. While the Syria constitution of 1973 declares all citizens equal under the law and forbids gender-based discrimination, having an official discourse is one thing and the reality on the ground another. While there is no doubt that these events are a very valuable source of empowerment to many Syrian women, the notion of 'mothers of the nation' did prevail in most of the representations. This has led to idealizing the role of the Syrian woman rather than discussing what still needs to do to improve the laws that protect her and further her empowerment.

Women in Syria have not yet acquired equal rights with regard to the personal status law and the penal and naturalization laws. For instance, as previously mentioned, when a Syrian man and Syrian woman establish a family, the woman is not granted the power of divorce or custody of the children; and there is no law that protects women from domestic violence. Many Syrian women are victims of domestic violence and are often subject to molestation and even rape or murdered on the pretext of preserving the family's "honor." These practices are tolerated because there are no laws that protect women from such misdeeds (Alous, 2017). Hence, all these social practices and arbitrary laws place women in an inferior position to men.

In the news reports surveyed above, only one unnamed Syrian woman reflected on these realities. Addressed the incidents of rape and torture, which occurred throughout the conflict, she called for the need to review the laws that will protect Syrian women in the future. She fell short, however, of calling for a change in laws. In general, the speech acts in the news reports did not call for notable changes in laws or policy reforms to the benefit of Syrian women. The news reports tended to focus predominately, if not entirely, on the idealization of 'the role of the Syrian woman.'

\subsubsection{Reflecting on other News Stories}

This part surveys the two remaining news stories. The groups of women in the reports are elderly Syrian women who support the Syrian Arab Army and young Syrian women in a public marriage ceremony.

On April 2, 2013, SAMA published a news report on a group of Syrian mothers who had been interviewed. The title of news story was 'Syrian mothers in the villages of Hama are preparing food for the Syrian Arab Army Heroes.' The report started with an old woman speaking on camera. She said: 
"Whatever we do, it won't be enough. May God bless them and give them victory."

The reporter then continued by describing the women preparing food for the fighters in the Syrian Arab Army:

"In these two hands, she was not able to carry weapons. However, with her two hands and with a heart full of hope, she prepared food for the heroes fighting on the frontlines. Meanwhile. she pushes away all the evil forces and terrorism. The women of the town of Salhab, on the country side of West Hama, have sent packages of food and medicine as well as first aid kits to the Syrian Arab Army fighting on the country side of Hama and Idlib."

The news report ended with a woman saying:

"We are trying to provide whatever we are able to in order to support the courageous men on the frontlines who are fighting to save Syria from terrorism, these men will eventually save us as well - because we are Syria."

In this news report, senior Syrian women were shown risking their lives to help the fighters of the Syrian Arab Army. The reporter's speech implied that these groups of elderly women were too weak to carry weapons, but that they joined 'the resistance' by providing support from their domestic realms. This could be read as a form of unarmed resistance. Their acts of resistance were tied to their obligation to fulfil their national and civil duty.

The notion of fulfilling one's national and civil duty also appears in a news report published on March 12, 2017 by RT Arabic. ${ }^{8}$ The title of the story was 'A Collective Wedding Celebrates 30 Syrian Arab Army Soldiers.' Thirty Syrian men, dressed in their military attire, walked down the streets of Aleppo with their brides dressed in white. The rest of the news story showed the Syrian police patrolling the streets on their motorbikes. It also showed the families dancing, feasting, and rejoicing the brides and grooms, as if the collective wedding celebrations were a national festivity and triumph. The Syrian brides walked into the public square and were praised as they took steps towards their 'motherhood.' In this setting, the act of marriage is represented as a kind of political calling rather than simply a social or ritual union of man and wife.

These images mirror the "idea of the Syrian collective family" that "is established through endlessly repeated narratives of sacrifice and familial loyis supportive of the Syrian regime (RT Arabic 2019). 
alty" to the Syrian regime (Haugbolle, 2008, p.264). The television representations emphasized the role of the mother and caregiver in Assad's Syria. On the one hand, these representations can be read as a reflection of how the Syrian constitution prioritizes the women's right to maternity leave and child care (Sparre, 2008). These laws are a symbol of state development and modernization. On the other hand, since the Syrian regime has made 'reproduction' a public rather than a private issue (Sparre, 2008), one could argue that the government's program on state feminism is ambiguous in nature.

\subsection{Motherhood in Relation to Agency}

In the television reporting, the notion of motherhood was visible in the representations of various groups of Syrian women. The ideal Syrian mother was described, idealized, and romanticized in the news reports. The ideal Syrian mother was depicted as a woman who works hard, properly raises her children thereby setting them on the right path to love the motherland and its leader, and as the young woman who fights for the motherland because she is a mother herself. Almost all of the Syrian women interviewed in the reports held high-ranking government positions. In their speech, they associated the value of work to a form of service that ought to be fulfilled by the Syrian community. Moreover, they claimed that both men and women equally have to fulfill a moral duty towards the Syrian state. When describing this moral duty among Syrian women, the reporting associated it with notions such as 'the power for work and the power for development.' Furthermore, women in Syria were described as 'a home in a homeland,' while also emphasizing women's role in building a better and stronger generation, one faithful to the Assad regime.

Although the Syrian women from the GUSW and Ba'ath spoke strongly in support of empowering Syrian women, their monologues emphasized the importance of being a 'devoted believer' to the Assad and Ba'ath ideology. These speech acts did not truly advocate for the Syrian women's independence, as much as they tried to encourage women to 'follow' the right path and eventually fulfill their role by becoming 'mothers of the nation.' Notions such as independent thought and making moral decisions regarding one's own responsibility were not truly endorsed in the reporting. It was as if Syrian women were not encouraged to think for themselves and make moral decisions on their own. Perhaps these ideological narratives eliminate the chances or limit 
the spaces in which Syrian women are able to express their 'individuality.' This loss of individuality is reproduced when the television narratives constantly dedicate aspects of a Syrian woman's life to serving the community and the nation as a whole. In other words, the television representations may have contributed to discouraging the individuality of the Syrian women. The image of 'the Syrian woman' and 'mother' was overshadowed by women's moral and national duties being speculated in the news.

Throughout the news reports, almost all Syrian women were framed in relation to the notion of 'we are Syria,' or 'we are the homeland.' These implications produce a political discourse around the Syrian women's bodies in which "the body itself no longer remains in the private sphere of the individual, but [is] subordinated to the national interest" (Pine 2003). It is as if, when Syrian women go to work in their private and public life, everything they do fosters the betterment of the people, and helps build a stronger nation. Similarly, becoming a mother, a caregiver, and a fighter for the motherland- or the holy land as Asma Al Assad described it- becomes or is seen as a national duty.

These ideas on the loss of individuality reflect on ideas introduced by Shereen Abuelnaga, an Egyptian socialist, feminist, and gender theorist (Kohl Journal, 2019). Abuelnaga (2018) writes:

"We women who live in Arab societies have been raised with the notion that our lives and bodies do not belong to us. And despite the disparities of our lived realities, philosophically, and materially, we are held to the same societal expectations when it comes to motherhood" (p. 198).

Thus, if a Syrian woman or girl fails to achieve her duties as 'a mother of the nation,' does she exist in the eyes of the state and her community? Abuelnaga (2018) asserted that the Arab women's role as a mother is a given, and it is her duty to fulfill it. More importantly, this particular role is decreed by social norms and not by the woman herself. Hence, we cannot perceive this role as a separate element disconnected from societal structures such as class, religion, and context. While Ba'ath claimed to promote the same equal rights and opportunities for men and women' Syrian women, unlike Syrian men, were expected to serve as mothers of the nation. This automatically reinforces the subjugation of Syrian women to gender binaries, thus reproducing patriarchal norms that govern their existence, body, and role in society.

Under the Syria regime, a woman's body has a role to fulfill in the public sphere and is no longer a private possession of the woman; rather, society ex- 
pects her to achieve her obligatory role as wife, mother, daughter, caregiver, teacher, etc. These compulsory roles become the basis of initializing forms of systemic power. In other words, the power of the Syrian state is being performed through the Syrian woman's body.

In light of this, could spaces such as the GUSW become a space of productivity or function as a 'harem,' where sites of struggle and acts of transgression take place? In other words, could the spaces occupied by women, in a male-dominated political party such as Ba'ath, become places where Syrian women can promote and speak about their personal and 'trivial' struggles? Could defiance take place, as opposed to the expected forms of compliance such as the assigned feminine roles of the Syrian women, or even the masculine ones that have been assigned to the Syrian female fighters? Additionally, is the Syrian woman 'only allowed to exist through someone else' (Abuelnaga, 2018), e.g., as a child, a husband, a brother, or a whole nation. Lastly, is there no other passage but the rite of passage to the ultimate stage of a woman's life: motherhood?

In the context of Assad's Syria, the function of womanhood has become directly tied to the reproduction of future children and motherhood to the nexus of nationhood. Throughout the news reports, we saw how the female members of the Ba'ath party viewed the capacity of Syrian women as mothers and thus as the crucial link to the modernization process, and even an effective source of passing the Syrian state's ideology onto future generations.

By perceiving childbearing and baring children as a national obligation, is it fair to say that all Syrian women - especially those who have been displaced or who come from middle and lower middle-class families - perceive the role of motherhood as a pure burden? Within this framework, I wish to refer back Abuelnaga (2018), an Arab woman and a professor at the American University of Cairo, and quote her personal journey, particularly how she resisted society's expectation of her becoming a mother. She writes in her short memoir:

"I am expected to raise them; bond with them; sacrifice for them; bear with all their absurdities; worry about their drowning; punish them; fulfill my dreams through them; impose my wishes on them; carry their picture in my handbag; cry and worry for them. If I am not a mother, then I am not complete. I, who did not make it to the rank of other, who plans her life without taking children into consideration, am not a mother, therefore I don't exist" (Abuelnaga, 2018, p. 198). 
But what if a woman aspires to raise her children, bond with them, sacrifice for them, and bear with them and for them? Does marriage not sometimes have a significant source of power and control among certain groups of women, especially women living in economically distressed communities or women living in exile? In certain contexts, marriage is the first step towards the bastions of support, honor, and familial respectability.

Afshar (1989) discussed marriage as an instrumentation that transfers control to women via reproduction and the marriage market, where women become the main organizers of choosing prospective marriage partners for their children, as well as undergoing the process of 'assessing their wealth, health, and suitability.' Building on his case study on Iranian society, Afshar (1989) wrote:

"...although men negotiate the actual marriage contract, women control the future of their children. Not surprisingly mothers see the process as desirable and empowering and a means of becoming something of a matriarch within the domestic sphere. As long as the traditional values are maintained, all mothers have the prospect of power and prestige. Once the married couple produces children, then grandmothers are accorded the prestige of the custodians of family health, welfare and morality. Traditional ceremonies run by women and for women initiate and protect each and every stage of child-rearing and enhance the authority of older women over the family as a whole" (p. 117).

These factors of married life and matriarchy are significant, especially for working class women. For many Syrian women, grandchildren are one of the main, if not the only available source of financial security at old age. Hence, entering grand-motherhood is cherished by many, and is perceived as an essential stage of life that provides them with familial control and authority. Therefore, we cannot limit our analysis and interpretation of motherhood, in the context of the Syrian conflict, as a solely patriotic duty or as a social obligation stemmed from patriarchy. While it is important to acknowledge, in a theoretical sense, that motherhood can be an institution that holds oppressive and patriarchal norms, we also cannot turn a blind eye to the maternal control many women acquire and aspire to acquire in their domestic spheres. Their role as mothers, aside from being a national obligation in Syria, may perhaps be publicly revered, especially among lower and lower-middle class communities in which women face difficulties gaining a secure livelihood. 
In this context, the Syrian women's domestic obligations may become a source of power and control. Repressive as they are, the Syrian state's policies that encourage the domestication of women, and a society that grants men, for instance, the right to forbid their wives from holding a waged employment and working in the mixed labor market, makes the role of the mother valued and appreciated among Syrian women. This brings the discussion to the 'enacting' function power enables. In this context, power embodies the Syrian regime narratives on motherhood, along with the patriarchal norms in Syrian society. Judith Butler (1997) explained how power can have an ambivalent function, one in which the subject subjected by this same power may emerge in two ways: "as the effect of a prior power and as the condition of possibility for a radically conditioned form of agency" (p. 14). Butler perceived agency as something power diverges unintendedly. In other words, this oppressive power also allows the emergence of "the ambivalent scene of agency," which represents the reversal of that power (Butler 1997, p. 15). "No subject comes into being without power... the subject produced by power becomes heralded as the subject who founds power" (Butler, 1997, p. 16). Butler's explanation may exemplify how women in Syria sometimes embrace the role of motherhood, assigned to them by the state and by society, as a way of paving their way through life and acquiring security and dominance through their matriarchal roles.

This sheds light on the importance of acknowledging the desires of the subjects under feminist thinking. Saba Mahmoud (2006) has argued that liberatory goals set by feminist theory have long situated desire in the same position as freedom and liberation. At times, these emancipatory feminist visions contrast with the cultures, desires, and sensibilities of third world women, particularly women in Arab Muslim cultures. Mahmoud (2006) wrote:

"It is quite clear that both positive and negative notions of freedom have been used productively to expand the horizon of what constitutes the domain of legitimate feminist practice and debate. For example, in the 1970s, in response to the call by white middle-class feminists to dismantle the institution of the nuclear family, which they believed to be a key source of women's oppression, Native and African American feminists argued that freedom, for them, consisted in being able to form families, since the long history of slavery, genocide, and racism had operated precisely by breaking up their communities and social networks" (p. 40). 
Here, Mahmoud's words echo Nazik al-Abid's testimony against the French colonialism in Syria and her activism and resistance against the Ottoman occupation of Syria. Interestingly, the name of Nazik Al Abid appears in Asma Al Assad's speech, as she addressed the historical accomplishments of Syrian women in the workforce. ${ }^{9}$ Thus, my argument would be to rethink the role of motherhood and what function it could have beyond its national, patriarchal, and stereotypical gender one.

On a similar note, the issue of sexual freedom becomes relevant to this discussion. The first section of this chapter argued that female fighters, who were able to escape patriarchy temporarily on the battlefield, are still not able to dictate their sexual freedoms. It is perhaps important to provide a rebuttal to my argument by acknowledging that not all Syrian women may support these particular liberatory feminist values, particularly not those related to sexual liberation. Many may perceive the rejection of marriage and raising a family as something shameful or unnatural. On the one hand, we may perceive this perspective as 'an ideology in practice;' on the other hand, we should also acknowledge that the process of enlightening certain groups of Syrian women on the repressive traditional norms of shame, modesty, and dignity is an emancipatory feminist vision that embraces hegemonic practices and hegemonic Western values. I am not saying that all Syrian women reject the idea of sexual freedom, nor that Western values should only be applied to women in Western cultures. Rather, I am attempting to establish an understanding on how this emancipatory (hegemonic) feminist vision may function as a form of enlightenment and is thus a vision that may comprehend these groups of women as "unenlightened".

This same vision can have a similar hegemonic function to that of the propagandic media narratives of the Syrian regime; namely Ba'ath's narratives on the 'mothers of the nation.' Evidently, these media narratives came from a source of authority; they also attempted to educate Syrian women about the role they ought to perform in society. I perceive Ba'ath's so-called modernization process as a form of hegemonic as well as a form of 'tanwir', Arabic for enlightenment. Educating different groups of women about existing or nonexisting provisions of family protection laws in Syria (as a way to learn about for national independence and for the women's right to work and vote in Syria (Zachs, 2013). 
one's rights and how to secure them), is a better approach than simply enlightening them.

If my feminist scholarship chose to understand the agency of these groups of Syrian women only through the acts of resisting the dominant male order or through the model of doing and undoing traditional social norms, does that not make my thoughts and my feminist writings part of the greater hegemonic feminist narrative that only articulates agency as a structure against the hegemonic male cultural norms of Arab Muslim societies? And if so, does it not make these two hegemonic practices opposite sides of the same coin? Both practices indulge in forms of enlightenment. The former pushes for the emancipation of Syrian women from the traditional social norms in Arab society, and latter pushes Syrian women to pursue those norms in keeping with societal expectations. In this line of argumentation, I find myself echoing Mahmoud's (2006) understanding on the importance of writing feminist thought without deploying one's own interests and agendas.

Lastly, it is important to point out two aspects ignored in the news reports. Firstly, the notion of fatherhood was not mentioned in any of the news reports. The synonyms used for motherhood and 'mothers of the nations' to describe notions about womanhood, the family; the state never incorporated the role of the father in the family and in building the future nation. Male figures in the family and society are dominant, especially in terms of setting the social norms, choosing whether the wife or the daughter should take up waged employment, and deciding whether the female members of the household are allowed to travel outside the country or not, etc. Throughout the news reports, we only saw one side of the narrative, one in which Syrian women were depicted through their role of raising brave men (and women). However, we never saw the role Syrian men play in their adulthood.

While the private role of the mother played in domestic sphere was framed as a national one, could Syrian women use their roles as mothers to make the personal political? Can this national duty become a space of contestation, where political agency is asserted within the framework of the family, society, and the state? Can the publicized private relations, bring personal topics related to womanhood into the public arena and politicize them, as opposed to keeping them in the trivial zone? 


\subsection{Conclusion}

This chapter surveyed news reports that depicted different groups of Syrian women practicing forms of armed and unarmed resistance. Throughout the news report analysis, I found that the Arab television news associated these forms of resistance with the role of motherhood in Syria. Thus, the notion of 'mothers of the nation' has prevailed in the news, as Syrian women were represented as the 'resisting subject' during the war.

The notion of the 'mother of the nation' is a common and stereotypical representation of women in war and conflict. This notion illustrates how dominant state narratives designate main roles for women as part of their participation in the national process (Anthias and Yuval-Davis, 1989). These roles could be traced in the Arab television news through the three main duties assigned to Syrian women: (a) The duty of child bearing; (b) the duty of transferring and maintaining culture and national identity; and (c) the duty of participating in armed and unarmed resistance. These duties are depicted as part of the Syrian women's role in serving the nation - the Assad regime.

Furthermore, I did not limit the analysis of the news reports to the (stereotypical) representations of women in war. I moved the account further to discuss how the subjectivation of Syrian women appeared in the news and discussed this subjectivation in relationship to the notion of agency. By referring to Butler's (1997) theory of subjectivation and Saba Mahmoud's (2006) concept of agency and the non-liberatory subject, I contextualized the visibility of the subject and the conditions of subjugation prevalent in the news reports. I addressed the problematic aspect of "reading agency primarily in terms of resistance to the regulatory power of structure of normativity" (p. 48) and suggested revisiting the notion of agency beyond the dualistic framework of upholding and dismantling social norms. In the upcoming chapter, I interpret and discuss the finding from Chapters 4 through 7 . 